\title{
INDICATORS OF BANKING FINANCIAL SECURITY: MACRO AND MICROECONOMIC LEVEL
}

\author{
Pestovskaya Zoya * \\ Ukraine, Dnepropetrovsk, Dzerzhinskogo street, 35/5, ap.64 \\ soledad74@ya.ru
}

\begin{abstract}
Keywords: financial security of the bank, threatening the financial security of banks, indicators of banking financial security.
\end{abstract}

Abstract: There is a definition of the concept of financial security of the bank, the article summarizes the existing and proposed new indicators of financial security banking.

\section{Introduction}

Thanks to the lessons of the financial crisis of 2008-2009, domestic banks are increasingly focused on protecting their own and borrowed funds from external and internal threats. Therefore, modern banks are forced to change security functions to tasks of which now should belong protective measures against the financial and economic threats, not just the physical security of the bank. That's why scientific researches aimed at developing mechanisms for the organization of financial security in today's banks are relevant and useful to guide banks and security for employees of banks.

The issue of financial security of banks is devoted a series of theoretical and practical development of domestic and foreign scientists Artemenko D., A. Baranovsky, Berdynskoho A., Bukyna S., A. Vinnikov, Hlazeva S., R. Gritsenko, Dobryn S., Yepifanova A., Yermoshenko M., Zachosovoy N., Zubko M., Leonov S., P. Matvienko, Plysetskoho D., Senchahova V., V. Shurpakova.

The aim of this study is the definition of financial security of bank, study of threats to the financial security of banks, generalization of existing and introduction of new financial indicators of the bank security.

The object of bank financial security is financial activity of bank, income, sources and amounts of financial resources, capital structure, cash flow structure, structure of assets, investments, financial risks, system of financial innovation.

\section{Results and Discussion}

Subjects of financial security are the bank's management and its personnel [1, p.74-78]. Factors of functional environment of the bank can be divided into external (economic, state, social, risky) and internal (commercial, institutional, personnel, technological, financial, information, risky) [2, p.92 -96].

Currently in the domestic and foreign economic literature the concept of bank security is sufficiently explored, are examined concepts such as "security of bank", "security of banking", "bank security", "economic safety of bank", "financial safety of commercial bank" but there is no single umbrella term.

However, a clear definition of the nature of the financial security impacts on: determination of the classification of banking security threats, their indicators; formation of the system of financial security of banks; reasonable formulation of the subjects and functions of the system.

Consequently, the economic literature treats the bank security as protection of interests of holders, customers, employees and management of bank against of internal and external threats; as organization of measures to prevent possible threats to its activities. 
The main characteristics of the financial security of the bank:

1) financial security - is one of the key elements of economic security of the bank;

2) financial security is characterized by quantitative and qualitative indicators;

3) performance of financial security should have thresholds for determining the financial security of the bank;

4) financial security of bank should ensure its development and stability (increase of market value, some financial advantages);

5) financial security provides protection of the financial interests of the bank, its customers and shareholders [3, p. 88].

Thus, the development of effective mechanism for improving the financial security of banks should be based on an assessment of threats to this security. However, at present there are no common approaches to assessing the security risks of commercial banks.

Consider factors which effect the financial safety of banks, as it is an important element in ensuring the financial security of enterprises, organizations and institutions, and economy of the country as a loss of confidence in banks harms the financial security of the state.

Important factors that affect the financial security of the bank:

- validity and unconditional compliance with prudential regulations that govern banking activities;

- $\quad$ bank liquidity (Ukrainian standards H4, H5, H6)

- $\quad$ safety of information,

- $\quad$ ensure profitability,

- $\quad$ norms of compulsory redundancy,

- $\quad$ overdue percent and prolonged credits,

- $\quad$ volume of refinancing from National Bank,

- $\quad$ the organizational structure of bank,

- $\quad$ salaries and motivation,

- $\quad$ quality of assets and liabilities structure management,

- $\quad$ confidence in the banking system,

- $\quad$ purchasing power of the national currency,

- $\quad$ competitive environment,

In addition to the task to ensure the financial security of both the bank and its customers, financial institutions should actively inform potential customers about the proper level of bank's financial security. One of the indicators of a stable financial safety of bank is its high credit rating, because the procedure of rating uses the indicators that are used in the process of assessing the level of financial security.

Domestic Ukrainian rating agencies in the establishment of rating of commercial banks take into account a list of factors of influence and indicators of bank [1, p.74-78]:

1. Factors of operating environment (current state of the banking system: the degree of competition from banks and non-bank financial institutions, general tendencies and existing problems of the financial services market, requirements of regulatory authorities to banking institutions, effectiveness of banking activity, methods of regulation and supervision, financial stability of the corporate sector (industries), possible directions of development, structure and level of population income, the dynamics of savings and costs (the level of welfare).

2. The position of banks in the financial market (quality and diversification of its customer base, the amount of assets of bank, the range of services rendered by the bank, availability, geographical diversification of branch network (outlets) of the bank, duration of the bank work in the financial market, qualifications, experience and stability of its top management, dependence on individual customers or operations, or markets and activities, the ability to access to new markets, the degree of sensitivity to changes in external conditions, evaluation of the degree of participation of the bank in the financial, banking, financial-industrial groups, advantages and disadvantages of 
such participation, the reputation of the bank and its significance for the financial market, the ability to attract resources from the state, from shareholders or associated companies, foreign investors).

3. Organization of corporate governance (composition of bank owners, their stake in the share capital, the impact of bank owners on formation of its strategy and current activities, the likelihood of a conflict of interests of different owners, trends in the composition of the owners, the consequences of such a change to the financial stability of the bank, organizational structure, personnel policy, procedure of management decisions, the quality of the system of collective bodies and clarity of the division of powers between them, the presence of an independent division of risk management and its role in the decision making process, the quality of strategic planning, presence of informative management reports and its use in the decision-making, the level of organization of the internal control and audit, bank transparency, completeness of information provided to the agency).

4. The level of risk management (institutions sensitivity to 5 main types of individual risks: credit, liquidity, market (currency, interest, price), operational-technological, legal).

5. Quality of financial management (financial indicators studied, which describe: capitalization and capital management, liquidity, quality and diversification of assets, liabilities diversification, efficiency of activity).

To assess the quality of capital management rating agencies analyze:

1) the equity structure of the bank;

2) the capital adequacy ratios;

3) the analysis of the bank's policy in terms of capital management, the availability and efficient use of internal and external sources of increasing capital.

To assess the quality of credit portfolio quality rating agencies analyze:

1) the concentration of bank on certain counterparties, industries and categories of borrowers, types of collateral and the possible impact of such concentrations in the bank's capital;

2) the level of security as a lender, which follows the structure of collateral and the volume of transactions with a high degree of credit risk (including loans and bill transactions with related parties);

3) the level of reservation of the loan portfolio, the level of bad debts and the dynamics of their change).

In an analysis of liabilities is analyzed the ratio of own and borrowed resources, diversification of liabilities involved by individual creditors and sources, level of unstable liabilities and assets with hypersensitivity to the background information.

In studying the effectiveness of the analyzed indicators of basic operations, return on assets and capital, ability to support the net interest margin and spread in a competitive financial market. Attention is paid to the diversification of sources of income, the share of fee income to total income, and level of impact of individual components of income and expenditure for the financial results of the institution.

Thus, rating evaluation provides participants with financial market information about the financial security of a bank.

In order to prevent mistakes in the system of financial security, the bank should use and improve mathematical methods of forecasting the dynamics of customer requirements, take the internal training programs of personnel, send workers for training in foreign banks, use financial incentives (bonuses to wages) to encourage employees to improve their own professional skills [4, p. 208-210]. For early detection of existing and potential shortcomings in the area of integrated financial security of the banking sector of Ukraine it is necessary to define the relevant indicators and carry out constant monitoring in order to take the necessary precautionary and preventive measures strengthening. 
Table 1

Indicators of banking financial security at the macro level [5]

\begin{tabular}{|c|c|c|c|c|c|c|c|c|c|c|c|c|}
\hline № & Name of indicator & 2007 & 2008 & 2009 & 2010 & 2011 & 2012 & 2013 & 2014 & 2015 & \multicolumn{2}{|l|}{ Norm. } \\
\hline 1 & 2 & 3 & 4 & 5 & 6 & 7 & 8 & 9 & 10 & 11 & 12 & \\
\hline 1. & $\begin{array}{l}\text { Share of banks with } \\
\text { foreign capital, \% }\end{array}$ & 26,86 & 28,80 & 28,02 & 31,25 & 30,11 & 30,11 & 27,22 & 31,22 & 33,33 & \multicolumn{2}{|l|}{$\leq 50^{*}$} \\
\hline 2. & $\begin{array}{l}\text { Gross external debt } \\
\text { to GDP, \% }\end{array}$ & 56,0 & 55,9 & 88,3 & 85,0 & 76 & 73,7 & 74,6 & 95,1 & 134,9 & \multicolumn{2}{|l|}{$\leq 50$} \\
\hline 3. & $\begin{array}{l}\text { Official reserves to } \\
\text { gross external debt, } \\
\%\end{array}$ & 40,62 & 31,03 & 25,63 & 29,47 & 25,19 & 18,23 & 14,37 & 5,91 & 10,31 & & \\
\hline 4. & $\begin{array}{l}\text { NBU discount rate } \\
\text { (average), } \%\end{array}$ & 8,0 & 12,0 & 10,25 & 7,75 & 7,75 & 7,6 & 6,5 & 14,0 & 24,9 & \multicolumn{2}{|l|}{$\leq 10$} \\
\hline \multirow[t]{4}{*}{5.} & \multirow{4}{*}{$\begin{array}{l}\text { NBU rate } \\
\text { of } \\
\text { mandatory } \\
\text { reserves } \\
\text { (average), } \\
\%\end{array}$} & 0,5 & 0,5 & 0 & 0 & 0 & 0 & 0 & 3 & 3 & \multirow{2}{*}{$\begin{array}{l}\text { for most } \\
\text { part of } \\
\text { bank } \\
\text { liabilities }\end{array}$} & \multirow[t]{2}{*}{2} \\
\hline & & 4 & 4 & 4 & 4 & 4 & 9 & 10 & 3 & 3 & & \\
\hline & & 1 & 1 & 0 & 0 & 0 & 0 & 0 & 6,5 & 6,5 & \multirow{2}{*}{$\begin{array}{l}\text { for } \\
\text { liabilities } \\
\text { over two } \\
\text { years }\end{array}$} & \multirow[t]{2}{*}{0} \\
\hline & & 5 & 5 & 7 & 7 & 8 & 10 & 15 & 6,5 & 6,5 & & \\
\hline 6. & $\begin{array}{l}\text { Money supply M3 } \\
\text { to GDP, \% }\end{array}$ & 54,97 & 54,40 & 53,35 & 55,23 & 52,07 & 54,91 & 61,86 & 60,88 & 53,02 & \multicolumn{2}{|l|}{$>50$} \\
\hline 7. & $\begin{array}{l}\text { The amount of cash } \\
\text { to GDP, \% }\end{array}$ & 17,00 & 17,67 & 18,67 & 18,48 & 15,92 & 15,86 & 17,87 & 19,46 & 16,16 & \multicolumn{2}{|l|}{$\leq 4$} \\
\hline 8. & $\begin{array}{l}\text { The volume of bank } \\
\text { lending to real } \\
\text { sector to GDP, \% }\end{array}$ & 36,14 & 46,80 & 50,61 & 46,28 & 43,71 & 43,10 & 47,22 & 49,71 & 45,70 & \multicolumn{2}{|l|}{$\geq 30-100$} \\
\hline 9. & $\begin{array}{l}\text { Money supply M2 } \\
\text { to GDP (level of } \\
\text { GDP monetization), } \\
\%\end{array}$ & 54,29 & 54,06 & 53,08 & 55,13 & 51,78 & 54,90 & 61,85 & 60,98 & 53,01 & \multicolumn{2}{|l|}{$>50-80$} \\
\hline 10. & \multirow{2}{*}{$\begin{array}{l}\text { Money supply M1 } \\
\text { to GDP, \% } \\
\text { Amount of reserve } \\
\text { assets of NBU to } \\
\text { annual imports, } \%\end{array}$} & 25,21 & 23,75 & 25,59 & 26,78 & 23,63 & 23,01 & 26,20 & 27,80 & 24,46 & \multicolumn{2}{|l|}{$>15-20$} \\
\hline 11. & & 45,01 & 31,55 & 47,16 & 47,21 & 32,12 & 24,34 & 20,97 & 10,75 & 32,87 & \multicolumn{2}{|l|}{$>25$} \\
\hline 12. & $\begin{array}{lrr}\text { Level of } & \text { cash } \\
\text { hryvnia } & \text { provision } \\
\text { with } & \text { official } \\
\text { reserves of } & \text { NBU, \% }\end{array}$ & 33,93 & 117,82 & 122,01 & 137,72 & 120,92 & 88,03 & 62,29 & 29,38 & 103,67 & \multicolumn{2}{|l|}{$>100$} \\
\hline 13. & $\begin{array}{l}\text { Annual inflation } \\
\text { rate, \% }\end{array}$ & 16,6 & 22,3 & 12,3 & 9,1 & 4,6 & $-0,2$ & 0,5 & 24,9 & 42,3 & $<20$ & \\
\hline 14. & $\begin{array}{l}\text { Velocity of money } \\
\text { supply (GDP to } \\
\text { M2), turns a year }\end{array}$ & 1,84 & 1,85 & 1,88 & 1,81 & 1,93 & 1,82 & 1,62 & 1,64 & 1,87 & $1-2$ & \\
\hline 15. & $\begin{array}{l}\text { Growth of primary } \\
\text { issue of NBU }\end{array}$ & 49,11 & 36,80 & 1,79 & 17,33 & 4,73 & 6,30 & 17,54 & 16,40 & $-3,01$ & $<20$ & \\
\hline 16. & $\begin{array}{l}\text { The interest rate on } \\
\text { government bonds, } \\
\% \text { p.a. }\end{array}$ & 11,56 & 11,86 & 12,21 & 10,39 & 9,17 & 12,94 & 13,13 & 13,44 & 13,36 & $<8,5$ & \\
\hline 17. & $\begin{array}{l}\text { Money multiplier } \\
\text { (M3 to monetary } \\
\text { base) }\end{array}$ & 2,79 & 2,76 & 2,50 & 2,65 & 2,86 & 3,02 & 2,95 & 2,86 & 3,02 & $*$ & \\
\hline 18. & $\begin{array}{l}\text { Saldo of corresp. } \\
\text { accounts of banks in } \\
\text { NBU, mln UAH }\end{array}$ & 19050 & 18622 & 17413 & 16726 & 21952 & 24691 & 33041 & 27224 & 26937 & $>20000^{*}$ & \\
\hline 19. & \begin{tabular}{lr}
\multicolumn{2}{l}{ Share of deposits of } \\
individuals & covered \\
by & Deposit \\
Guarantee & Fund \\
resources & of \\
individuals, \% & \\
\end{tabular} & 0,86 & 1,46 & 2,17 & 1,33 & 1,71 & 1,80 & 1,81 & 4,42 & 5,09 & $>10-30^{*}$ & \\
\hline
\end{tabular}

Notes: * Proved by author. 
Bank financial security depends on many external and internal factors, so it should be considered at two hierarchical levels: financial security of the NBU (macro level) and financial security of individual banking institutions (micro level).

For early detection of existing and potential shortcomings in the area of financial security of banking activity in Ukraine should determine its appropriate indicators, and lead constant monitoring of them in order to implement the necessary measures.

The main indicator of the importance of banking to the economy is the ratio of bank assets to GDP.

Financial security is characterized by the following indicators: the proportion of foreign capital in total capital, the share of problem loans in the loan portfolio of the bank, indicating that risky credit policy; the ratio of highly liquid funds and current liabilities (liquidity), which shows the extent of its protection against the risk of withdrawal of funds once by all clients; the ratio of own and borrowed funds, which reflects the level of reliability of the bank in the long term; return on net assets, average assets per employee, internal cost of banking services, efficiency ratio of borrowed funds.

Macroeconomic indicators characterize the level of indirect effect on the financial safety of a particular bank and determined the level of financial security of state (tab. 1).

Comparison of the banking system during 2007-2015 with thresholds of macroeconomic indicators showed that ratio of gross debt to GDP since 2007 exceeds the safe threshold, the ratio of M3 since 2007 far exceeds the safety threshold, but gradually returned to normal values, the volume of cash to GDP is historically much higher than standard value; even taking into account that there are different views on threshold is close to the lower version, the same applies to the monetization of GDP (M2 to GDP), but M1 shows a safe value, yield of government securities much higher than permanent safe threshold.

Graph showing the proportion of deposits covered by the Deposit of individuals Guarantee Fund's resources speaks for itself - now it is only $5 \%$.

Regular contributions are made on Deposit of individuals Guarantee Fund by the well developed model and depend on the specific parameters of the deposit portfolio of the bank.

Deposit of individuals Guarantee Fund also receives income from the sale of problem banks transferred to it.

After an increase in 2014 from 120 to 500 million UAH requirements to the size of the authorized capital of newly established banks, the purchase of problem bank from Deposit of individuals Guarantee Fund is one of the two real variants of entering the banking market, along with the purchase of shares from existing holders.

In addition, you can see that deposit - relatively stable part of borrowed funds - are safe thanks to deposits of individuals, but long-term loans (exceeding one year) are not covered even with term deposits (duration of most of which doesn't exceed one year), quality of assets also doesn't reach a safe level, and financial results and generally have a negative value since the financial crisis.

Evaluation of financial security at the micro level is divided in the following groups (tab. 2):

1. The figures, based on the structure and adequacy of capital;

2. The figures, based on the structure of attracted and borrowed funds;

3. The indicators of assets quality;

4. Liquidity;

5. Profitability;

6. Currency safety.

Comparison of indicators of banking system during 2007-2015 with thresholds of microeconomic indicators showed that the share of capital in liabilities consistently exceeds the threshold, so is within safety limits, standards H2, H3-1, H4, H5, H6 were also in safe limits except current 2015 year. 
Table 2

Indicators of banking financial security at the micro level [5]

\begin{tabular}{|c|c|c|c|c|c|c|c|c|c|c|c|}
\hline № & Name of indicator & 2007 & 2008 & 2009 & 2010 & 2011 & 2012 & 2013 & 2014 & 2015 & Norm. \\
\hline 1 & 2 & 3 & 4 & 5 & 6 & 7 & 8 & 9 & 10 & 11 & 12 \\
\hline \multicolumn{12}{|c|}{ The figures, based on the structure and adequacy of capital } \\
\hline 1. & $\begin{array}{l}\text { The share of capital in } \\
\text { liabilities, } \%\end{array}$ & 11.6 & 12.9 & 13.1 & 14.6 & 14.7 & 15,02 & 15,07 & 11,24 & 9,95 & $\geq 9^{*}$ \\
\hline 2. & $\begin{array}{l}\text { The regulatory capital } \\
\text { to assets weighted by } \\
\text { risk }(\mathrm{H} 2), \%\end{array}$ & 13,92 & 14,01 & 18,08 & 20,83 & 18,90 & 18,06 & 18,26 & 15,60 & 9,90 & $\geq 10$ \\
\hline 3. & $\begin{array}{l}\text { Reliability ratio } \mathrm{H} 3-1 \\
\text { (regulatory capital to } \\
\text { liabilities), } \%\end{array}$ & 13,64 & 15,25 & 17,75 & 20,00 & 19,85 & 18,28 & 17,41 & 13,89 & 9,83 & $>10$ \\
\hline \multicolumn{12}{|c|}{ The figures, based on the structure of attracted and borrowed funds } \\
\hline 4. & $\begin{array}{l}\text { The share of term funds } \\
\text { of economic entities, } \%\end{array}$ & 48,39 & 50,96 & 43,84 & 38,38 & 39,87 & 45,81 & 44,57 & 39,23 & 30,05 & $>50^{*}$ \\
\hline 5 . & $\begin{array}{l}\text { The share of time } \\
\text { deposits of individuals, } \\
\%\end{array}$ & 76,84 & 82,14 & 73,90 & 76,32 & 77,54 & 79,43 & 80,88 & 76,64 & 74,35 & $>50^{*}$ \\
\hline 6. & $\begin{array}{l}\text { Cover long-term loans } \\
\text { with term deposits of } \\
\text { businesses } \\
\text { individuals, } \%\end{array}$ & 61,59 & 48,94 & 46,56 & 62,35 & 73,09 & 61,40 & 72,37 & 52,52 & 45,83 & $>100^{*}$ \\
\hline \multicolumn{12}{|c|}{ The indicators of assets quality } \\
\hline 7. & $\begin{array}{l}\text { The share of overdue } \\
\text { loans in their total, } \%\end{array}$ & 1,31 & 2,27 & 9,36 & 11,24 & 9,61 & 8,9 & 7,7 & 13,5 & 20,4 & $\leq 2^{*}$ \\
\hline 8. & $\begin{array}{l}\text { The average interest } \\
\text { rate on loans to the real } \\
\text { sector,\% p.a. }\end{array}$ & 13,1 & 15,5 & 18,0 & 14,0 & 14,4 & 17,5 & 14,4 & 16,4 & 20,8 & $\leq 10$ \\
\hline 9. & $\begin{array}{l}\text { The share of loans to } \\
\text { the real sector in total, } \\
\%\end{array}$ & 53,61 & 56,26 & 60,00 & 63,53 & 67,13 & 74,26 & 75,92 & 77,39 & 89,46 & $>50$ \\
\hline 10. & $\begin{array}{l}\text { The share of loan } \\
\text { portfolio in the assets of } \\
\text { banks, } \%\end{array}$ & 80,98 & 85,55 & 84,90 & 80,14 & 78,28 & 72,33 & 71,31 & 76,42 & 75,01 & $>45$ \\
\hline 11. & $\begin{array}{l}\text { Total assets of the } \\
\text { banking system to } \\
\text { GDP, } \%\end{array}$ & 83,17 & 97,68 & 96,38 & 87,02 & 80,08 & 80,25 & 87,23 & 84,05 & 68,10 & $>80$ \\
\hline \multicolumn{12}{|c|}{ Liquidity } \\
\hline 12. & $\begin{array}{l}\mathrm{H} 4 \text { Instant liquidity } \\
\text { ratio, } \%\end{array}$ & 53,60 & 62,38 & 64,45 & 58,80 & 58,48 & 68,26 & 56,99 & 57,13 & 70,64 & $\geq 20$ \\
\hline 13. & $\begin{array}{l}\text { H5 Current liquidity } \\
\text { ratio, } \%\end{array}$ & 75,31 & 75,16 & 72,90 & 77,33 & 70,53 & 79,09 & 80,86 & 79,91 & 80,59 & $\geq 40$ \\
\hline \multirow[t]{2}{*}{14.} & H6 Short-term liquidity & 39,93 & 32,99 & \multirow[t]{2}{*}{35,88} & \multirow[t]{2}{*}{91,19} & \multirow[t]{2}{*}{94,73} & \multirow[t]{2}{*}{90,28} & \multirow[t]{2}{*}{89,11} & \multirow[t]{2}{*}{86,14} & \multirow[t]{2}{*}{88,30} & \multirow[t]{2}{*}{$\geq 60$} \\
\hline & ratio, $\%$ & & & & & & & & & & \\
\hline \multicolumn{12}{|c|}{ Profitability } \\
\hline 15. & $\begin{array}{l}\text { Financial results of } \\
\text { banks, mln UAH }\end{array}$ & 6630 & 7304 & -38492 & -13027 & -7708 & 4899 & 1436 & -52966 & -56251 & $>0$ \\
\hline 16. & ROE, $\%$ & 12.67 & 8.51 & -32.52 & -10.19 & -5.27 & 3.03 & 0.81 & -30.46 & -51.34 & 15 \\
\hline 17. & ROA, $\%$ & 1.50 & 1.03 & -4.38 & -1.45 & -0.76 & 0.45 & 0.12 & -4.07 & -5.55 & 3 \\
\hline \multicolumn{12}{|c|}{ Currency safety } \\
\hline 18. & $\begin{array}{l}\text { Foreign currency loans } \\
\text { to total loans, } \%\end{array}$ & 51,45 & 60,32 & 52,59 & 48,23 & 42,13 & 37,66 & 34,72 & 47,77 & 54,85 & \\
\hline 19. & $\begin{array}{l}\text { Liabilities in } \begin{array}{r}\text { foreign } \\
\text { currency to } \\
\text { liabilities, } \%\end{array} \\
\end{array}$ & 49,77 & 59,04 & 55,83 & 51,25 & 49,76 & 49,22 & 43,25 & 49,27 & 52,55 & \\
\hline
\end{tabular}

Notes: * Proved by author. 
Lack of bank liquidity may be caused by faulty analysis of the gap between assets and liabilities; significant dependence on the current liabilities during investing in long-term assets; significant dependence on subordinated debt; low reputation in the interbank market.

In case of any problems associated with loss of the capital a bank has to avoid: inadequate growth of assets; conflicts of interest between shareholders; reduction of capital due to payment of dividends or too big bank return of funds raised subordinated debt; losses associated with the need to create the necessary reserves for active operations as a result of the deterioration of their quality.

This situation requires the development of modern approaches to the assessment of the reliability of banks, so as not to be among those depositors who for months could not get their money back.

One of the most important indicators of the financial condition of the bank is its profitability, but it can't be considered without taking into account the factors that shape it.

The bank's income should cover all its costs and the formation of reserves for active operations. For a full analysis of bank activity we must consider the level of it's liquidity.

A characteristic feature of having problems are the low levels of highly liquid assets (cash in cash office and correspondent accounts, government bonds), though ideally they should cover the current liabilities to clients and loans from NBU.

It is also necessary to analyze the volume of attracted resources from interbank market.

The resource base of the bank should be evaluated over time, if significant outflow of client funds is revealed, it may indicate a problem with the return of loans.

To external observer it is difficult to estimate the asset quality, but if bad debts amounted to more than $10 \%$ of the portfolio, it is a negative signal.

Also the analysis of the Bank's equity is required: share capital increase, a redistribution of income in favor of the bank said about the responsibility of shareholders to support and develop the bank.

An important criterion of the bank reliability is a successful combination of retail and corporate business.

Even banks with no profits can be reliable because they may have a different distribution of cash flows: to direct funds for the opening of new sales outlets, the launch of a new activity.

Alternatively, the bank may send a large portion of the profits on the formation of reserves for loans and to be reliable with minimum profit.

\section{Conclusion}

An analysis of macro and micro indicators of banks' security makes the following conclusions: the level of implementation of mandatory economic standards of the banks is at a sufficient level, but the greatest negative impact on the stability of the banking system is the financial policy of government and monetary policy of NBU and failures of specialists of many banks on the consistency of assets and liabilities of banks on the terms and amounts that requires some additions to Instruction on regulation of banks in Ukraine with the relevant regulations, proposed by the author (tab. 1,2).

Further research in this area includes the study of international practice of assessing the financial security of banks, search and justification of optimal thresholds of security indicator for banks.

Thus, according the results of this study we can conclude that adequately assess of the existing level of bank security influences the completeness, timeliness and effectiveness of management of elimination and prevention of existing and potential threats to the banking system, and therefore - the entire national economy. 


\section{References}

[1] Zachosova N. Features of provide financial security of commercial banks in Ukraine. Scientific Bulletin: Finance, banks, investment. (2011). V.4, 74-78.

[2] Dobryn S. Analysis of impact factors of financial security for the financial stability of banks / Bulletin of the economy and transport industry. (2010). V., 92-96.

[3] Poberezhny S., Dadashev B., Plastun A. Models and methods of banking security: monograph, Sumy, UAB NBU, 2010.

[4] Yepifanov A., Plastun O., Dombrovsky V. Financial security of companies and banks: monograph, Sumy, UAB NBU, 2009.

[5] Information on http://www.bank.gov.ua/files/stat.pdf. 